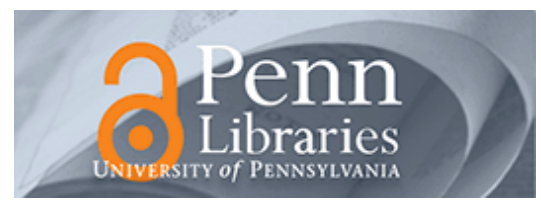

University of Pennsylvania

ScholarlyCommons

$10-2013$

\title{
The Effect of Rising Income Inequality on Taxation and Public Expenditures: Evidence from U.S. Municipalities and School Districts, 1970-2000
}

Leah Boustan

Fernando V. Ferreira

University of Pennsylvania

Hernan Winkler

Eric M. Zolt

Follow this and additional works at: https://repository.upenn.edu/real-estate_papers

Part of the Economics Commons, Real Estate Commons, and the Taxation Commons

\section{Recommended Citation}

Boustan, L., Ferreira, F. V., Winkler, H., \& Zolt, E. M. (2013). The Effect of Rising Income Inequality on Taxation and Public Expenditures: Evidence from U.S. Municipalities and School Districts, 1970-2000. The Review of Economics and Statistics, 95 (4), 1291-1302. http://dx.doi.org/10.1162/REST_a_00332

This paper is posted at ScholarlyCommons. https://repository.upenn.edu/real-estate_papers/53

For more information, please contact repository@pobox.upenn.edu. 


\title{
The Effect of Rising Income Inequality on Taxation and Public Expenditures: Evidence from U.S. Municipalities and School Districts, 1970-2000
}

\author{
Abstract \\ The income distribution in many developed countries widened dramatically from 1970 to 2000 . Some \\ scholars argue that income inequality contributes to a host of social ills by undermining voters' \\ willingness to support public expenditures. In contrast, we find that growing income inequality is \\ associated with an expansion in government revenues and expenditures on a wide range of services in \\ U.S. municipalities and school districts. Results are robust to a number of model specifications, including \\ instrumental variables that address the endogeneity of the local income distribution. Our results are \\ inconsistent with models predicting that heterogeneous societies provide lower levels of public goods. \\ Disciplines \\ Economics | Real Estate | Taxation
}




\title{
THE EFFECT OF RISING INCOME INEQUALITY ON TAXATION AND PUBLIC EXPENDITURES: EVIDENCE FROM U.S. MUNICIPALITIES AND SCHOOL DISTRICTS, 1970-2000
}

\author{
Leah Boustan, Fernando Ferreira, Hernan Winkler, and Eric M. Zolt*
}

\begin{abstract}
The income distribution in many developed countries widened dramatically from 1970 to 2000. Some scholars argue that income inequality contributes to a host of social ills by undermining voters' willingness to support public expenditures. In contrast, we find that growing income inequality is associated with an expansion in government revenues and expenditures on a wide range of services in U.S. municipalities and school districts. Results are robust to a number of model specifications, including instrumental variables that address the endogeneity of the local income distribution. Our results are inconsistent with models predicting that heterogeneous societies provide lower levels of public goods.
\end{abstract}

\section{Introduction}

$\mathrm{O}$ VER the past thirty years, the income distribution has widened dramatically in the United States and many other developed countries (Piketty \& Saez, 2003; Smeeding, 2004). Income inequality is correlated with several negative outcomes, including high crime rates, low levels of education achievement, and poor health. ${ }^{1}$ Yet little is known about whether these relationships are causal and, if so, the channels through which a widening income distribution might translate into these social ills.

One frequently proposed mechanism for the relationship between inequality and social outcomes is that income inequality reduces voters' willingness to support taxation and public expenditures. Some political economy models suggest that in heterogeneous societies, residents cannot agree on the composition of public goods or on the taxes and charges used to fund them (Benabou, 1996, 2000). In particular, rich households may rely on private alternatives to public goods, and the poor may prioritize personal consumption over public contributions, generating dissent between the ends and the middle of the income distribution (Epple \& Romano, 1996). ${ }^{2}$ On the other hand, models based on the median voter theorem predict that a widening of the income distribution will encourage the electorate to support higher taxes and greater public expenditures, provided that the absolute tax burden increases with income while the

Received for publication August 15, 2010. Revision accepted for publication July 17, 2012.

* Boustan: UCLA and NBER; Ferreira: Wharton School, University of Pennsylvania, and NBER; Winkler: World Bank; Zolt: UCLA School of Law.

We received useful comments from seminar participants at UCLA, UC Berkeley School of Law, and National Tax Association meetings. We gratefully acknowledge financial support from the UCLA Ziman Center for Real Estate and the Research Sponsor Program of the Zell/Lurie Real Estate Center at Wharton.

${ }^{1}$ See Kawachi et al., (1997), Kennedy et al., (1998), Fajnzylber, Lederman, \& Loayza (2002), and the research summarized in Wilkinson and Pickett (2009). For an opposing view, see Deaton and Lubotsky (2003).

${ }^{2}$ Heterogeneity can also reduce social capital between residents, which may undermine trust, norms of reciprocity, and support for local government activity (Putnam, 2000; Boix \& Posner, 1998; Costa \& Kahn, 2003). benefits of government activity are more equally shared (Meltzer \& Richard, 1981; Alesina \& Rodrik, 1994; Persson \& Tabellini, 1994). Residents of unequal societies may also have greater needs, leading altruistic voters to support social programs.

Existing empirical work has not established a definitive relationship between income inequality and the size of the public sector. ${ }^{3}$ Two types of identification problems complicate estimation of the empirical relationship between income inequality and public goods provision. The crosscountry variation often used for this exercise suffers from omitted variable bias; that is, countries with high income inequality may also have other characteristics that could limit the size of the public sector. Cross-state comparisons also suffer from endogenous household sorting. If low- or high-income families migrate to states with high public expenditures, the positive association observed in the literature between state public expenditures and income inequality may be spurious.

In this paper, we examine the relationship between income inequality and government finances in municipalities and school districts in the United States from 1970 to 2000. Local government represents a large segment of the economy; in fiscal year 2009, local governments disbursed more than $\$ 3$ trillion for such important services as education and public safety. ${ }^{4}$

Our study has several advantages over existing empirical work. First, the large number of local governments in our data exhibit much greater variation in income inequality over time than do the small number of countries or states used in previous studies. A large sample size allows us to separately control for changes in the top end or bottom end of the income distribution and for initial levels of inequality, thus ruling out a mechanical association between tax revenues and rising income for the affluent. Second, we develop an instrumental variable strategy to mitigate concerns about potential reverse causality from the endogenous

\footnotetext{
${ }^{3}$ In a cross-section of countries, results tend to show that countries with high levels of inequality, like the United States, engage in less public spending (see, for example, Lindert, 1994, 1996; Moene \& Wallerstein, 2005; Schwabish, Smeeding, \& Osberg, 2006; an exception is Shelton, 2007). In contrast, comparisons across U.S. states and within states over time find that rising income inequality is accompanied by higher government expenditures and increasing progressivity in the state tax code (Chernick, 2005; Schwabish, 2008).

${ }^{4}$ State governments accounted for $\$ 1.36$ trillion in expenditures in 2009, while all other local governments (cities, school districts, and so on) accounted for $\$ 1.72$ trillion. The federal government spent $\$ 3.52$ trillion in 2009. Beyond cities and school districts, counties and special districts also provide local services, although these governmental units represent a relatively small share of the total expenditures. These facts were compiled from http://www.usgovernmentspending.com/.
} 
sorting of households across localities. Our instrument predicts the income distribution in a city or school district at a point in time by applying the national patterns of income growth to the initial (1970) income distribution in an area. By design, our instrument cannot be influenced by mobility into and out of communities; rather, it isolates the component of change in the local income distribution that is driven by national trends, such as changes in the return to skill and in labor market institutions. ${ }^{5}$

We find no evidence that an increase in income inequality reduces expenditures on public services in cities or school districts; rather, as the income distribution widens, localities increase their revenue collection and expenditures. Our preferred IV estimate suggests that the average increase in the city-level Gini coefficient (5 points) leads to an $\$ 88$ increase in expenditures per resident and can explain $22 \%$ of the growth in municipal expenditures over this period. We rule out a mechanical relationship between rising top-end inequality and the size of the local tax base by flexibly controlling for the share of households in each segment of the income distribution. Among school districts, the average change in the Gini is associated with a $\$ 514$ increase in local property tax revenue per pupil with a corresponding $\$ 697$ decline in state transfers, values that are proportional to the effects of inequality on municipal spending due the higher levels of educational expenditures. In other words, it appears that state systems of school finance equalization have undone much of the effect of rising income inequality on local revenue collection at the school district level.

We also investigate how changes in the income distribution affect the composition of local expenditures. Rising income inequality leads to extra spending on police services, fire protection, and road maintenance. In related results, we find that growing racial fractionalization is correlated with larger government expenditures across a wide range of expenditure categories, casting doubt on earlier findings that more racially fragmented cities spend a smaller share of their budget on public goods (Alesina, Baqir, \& Easterly, 1999; see also Cutler, Elmendorf, \& Zeckhauser, 1993; Hopkins, 2009).

Our results are consistent with recent work by Corcoran and Evans (2010), which documents a positive relationship between income inequality and educational expenditures at the school district level. ${ }^{6}$ These findings challenge the hypothesis that income inequality reduces the provision of public goods from local governments in the United States because heterogeneous societies are unable to compromise

\footnotetext{
${ }^{5}$ A full review of the literature on the causes of rising inequality is beyond the scope of this paper. Recent work by Autor, Katz, and Kearney (2006) emphasizes that technological change is complementary with both low- and high-skilled labor, leading to polarization in the labor market. For a discussion on the role of labor market institutions, see Blau and Kahn (1996) and Lee (1999) specifically on the minimum wage.

${ }^{6}$ Our results were generated independent of Corcoran and Evans's (2010) recent study. We reach similar conclusions despite using different methods to measure income inequality within school districts and developing a different instrument for changes in inequality at the local level.
}

on common public goods and services. ${ }^{7}$ Our results are instead supportive of a median voter model, which posits that rising inequality lowers the tax price of public services for the median voter.

The applicability of the median voter framework depends on the institutional setting. In particular, the median voter model addresses tax revenue that is both raised and spent in the same locality. Yet by 2000 , over half of all school funding was provided by the state in the form of intergovernmental transfers. We show that this centralized funding arrangement counteracts the positive relationship between income inequality and locally raised property tax revenue within school districts. Furthermore, predictions from the median voter model depend on both the incidence of the tax instruments used to raise revenue and the distribution of benefits from the resulting expenditures. We explore variation by revenue source and expenditure category; overall, we find a positive relationship between income inequality and all categories of government activity.

The remainder of the paper is organized as follows. The next section discusses our measures of income inequality and government activity at the local level. Section III describes our panel estimation, as well as an instrument for changes in the local income distribution. Section IV documents the positive relationship between changes in local inequality and growing revenues and expenditures at the city and school district levels. Section V concludes.

\section{Data on Income Distribution and Government Activity at the Local Level}

\section{A. Income Inequality}

We collect decadal data on the income distribution and expenditures and revenues from 1970 to 2000 for a large number of cities and school districts. Our municipality and school district samples consist of balanced panels of every Census-defined place (incorporated city or town) or school district with 2,500 or more residents in 1970. We exclude the 903 municipalities that were directly responsible for providing education services, leaving us with a sample of 3,383 cities and towns and 8,884 school districts. ${ }^{8}$ Note that the majority of our municipal sample is made up of small

\footnotetext{
${ }^{7}$ However, previous work using historical data at the state or local level finds that, before World War II, unequal communities raised less local revenue and provided fewer common goods and services (Goldin \& Katz, 1999; Ramcharan, 2010; Galor, Moav, \& Vollrath, 2009; Zolt, 2009).

${ }^{8}$ The Census of Population provides demographic information for 11,687 and 14,405 school districts in 1970 and 2000, respectively. We use the School District Geographic Reference File for 1970 to combine the demographic information with expenditure data from the Census of Governments. The sample consists of the 8,884 school districts that could be matched between 1970 and 2000. This sampling rule eliminates school districts that eventually disappear from the data due to consolidations with other districts. We choose not to aggregate districts that eventually consolidate because the political economy mechanism that we have in mind pertains to the actual voters and residents of a district. As a result, a component of the measured variation in income inequality over time within a district will be due to mergers with neighboring districts.
} 
Table 1.-Summary Statistics: Municipal and School District Revenues and Expenditures, 1970-2000

\begin{tabular}{|c|c|c|c|c|c|c|c|}
\hline & \multicolumn{7}{|c|}{ A. Municipalities (per capita) } \\
\hline & $\begin{array}{c}\text { Gini } \\
\text { Coefficient }\end{array}$ & $\begin{array}{l}\text { General } \\
\text { Revenue }\end{array}$ & $\begin{array}{l}\text { Property } \\
\text { Tax }\end{array}$ & $\begin{array}{l}\text { Intergovernmental } \\
\text { Transfers }\end{array}$ & $\begin{array}{c}\text { Direct } \\
\text { Charges }\end{array}$ & $\begin{array}{l}\text { Sales } \\
\text { Tax }\end{array}$ & $\begin{array}{c}\text { Other } \\
\text { Revenue }\end{array}$ \\
\hline \multicolumn{8}{|l|}{ Revenue } \\
\hline 1970 mean & 0.320 & 446.7 & 146.5 & 95.0 & 89.5 & 3.1 & 117.0 \\
\hline 1970 SD & $(0.054)$ & $(301.9)$ & $(117.5)$ & $(143.2)$ & $(143.2)$ & $(7.1)$ & $(166.9)$ \\
\hline \multirow[t]{3}{*}{$\Delta 1970-2000$} & 0.055 & 426.9 & 44.1 & 104.7 & 104.7 & 57.3 & 123.4 \\
\hline & General & & & & Public & Health and & Other \\
\hline \multirow{2}{*}{\multicolumn{8}{|c|}{ Spending }} \\
\hline & & & & & & & \\
\hline 1970 mean & 458.9 & 75.6 & 31.2 & 60.3 & 0.5 & 20.4 & 272.7 \\
\hline 1970 SD & $(436.5)$ & (45.3) & (34.4) & $(34.9)$ & $(7.7)$ & $(117.1)$ & (398.4) \\
\hline$\Delta 1970-2000$ & 408.3 & 56.5 & 20.0 & 9.8 & 1.6 & 10.4 & 308.8 \\
\hline & \multicolumn{7}{|c|}{ B. School Districts (per pupil) } \\
\hline & Gini & Total & Total & Property & State & Direct & Other \\
\hline & Coefficient & Revenue & Expenditures & Tax & Transfers & Charges & Revenue \\
\hline 1970 mean & 0.329 & 4005.4 & 3937.6 & 1900.7 & 1828.8 & 212.7 & 296.0 \\
\hline 1970 SD & $(0.052)$ & $(1407.6)$ & $(1622.9)$ & (1354.7) & $(869.8)$ & $(157.8)$ & $(268.9)$ \\
\hline$\Delta$ 1970-2000 & 0.034 & $3,626.4$ & $3,739.0$ & 763.0 & $2,534.2$ & 15.7 & 307.6 \\
\hline
\end{tabular}

towns: $65 \%$ of the municipalities in the sample have fewer than 10,000 residents.

Because of Census privacy restrictions, we cannot recover the full income distribution at the local level. Instead, we use published Census reports, which indicate the number of households in a jurisdiction in each of fifteen to twenty income categories, to generate an (approximate) income distribution. We assign each household an income level equal to the median income in its bin by decade as calculated from Census microdata. We then generate Gini coefficients at the local level for this modified income distribution. ${ }^{9}$

In 1970, the average municipality in our sample had a Gini coefficient of 0.32, compared to the national Gini coefficient of 0.39 (table 1). By 2000, the Gini coefficient in the average municipality increased by 5.5 points to 0.38 . However, the average increase obscures a tremendous variation across municipalities. The Gini coefficient increased by less than 1 point (or even decreased) in one-third of the cities in our sample, while in another third, the Gini coefficient increased by more than 5 points.

\section{B. City Finances}

The Census (and Surveys) of Governments provide information on municipal revenues and expenditures by detailed category. The first panel of table 1 contains summary statistics on the sources of revenue and the categories of current expenditures at the municipality level. All values are reported in year 2000 dollars. In the average municipality, expenditures per resident doubled from $\$ 459$ in 1970 to $\$ 867$ by 2000 . Spending on infrastructure, including roads,

\footnotetext{
${ }^{9}$ Without a full set of microdata at the municipal level, we are unable to calculate other measures of inequality, such as the 90-10 ratio, with sufficient accuracy.
}

sewers, water, and electricity, comprises $44 \%$ of average municipal budgets, while spending on police and fire protection makes up another $21 \%$. In comparison, redistribution in the form of direct public welfare and expenditures on health and public hospitals contributes a negligible amount (less than 5\%) of the typical municipal budget.

In 1970, property taxes were the largest source of municipal revenue, accounting for 33\% of total proceeds. By 2000, property taxes declined to only $22 \%$ of revenue, replaced in large part by intergovernmental transfers and direct charges for services. ${ }^{10}$ Sales taxes also increased from very low levels in 1970 to $12 \%$ of total revenue in 2000 . Property and sales taxes tend to be regressive in the sense that they require higher tax payments as a share of total income from poor households (Suits, 1977; Phares, 1980). ${ }^{11}$ Direct charges may be even more regressive than property taxation because they are levied on a per house basis rather than tied to the value of the home. ${ }^{12}$ On the other side of the ledger, intergovernmental transfers are often financed through progressive state or federal income taxes; however, the tax burden for these transfers may disproportionately fall on households living outside the locality in question.

We caution that higher government expenditures need not be synonymous with a higher quality or quantity of public services for the average resident. First, the majority of

\footnotetext{
${ }^{10}$ The relative decline in property taxes from 1970 to 2000 was part of a larger decline in the use of local property taxes over the twentieth century (Oates \& Schwab, 2004; Sokoloff \& Zolt, 2005). This trend was accelerated in the 1980s by statutory limits on the level or growth of property tax rates in some states.

${ }^{11}$ Specific features of the tax system, including exemptions for food and other items from sales taxes or initial threshold exemptions from property taxes, can affect the incidence of these instruments. There is significant scholarly debate about the true incidence of the property tax (see Mieszkowski, 1972; Aaron, 1974; Musgrave, 1974; Hamilton, 1976).

${ }^{12}$ The largest categories of direct charges are for sewers (23\%), hospitals (20\%), airports (8\%), and sanitation services (8\%).
} 
government expenditures covers the wages and salaries of municipal workers, increases in which may not translate into a higher quality of service provision. Second, anecdotal evidence suggests that a greater share of city services is directed toward high-income neighborhoods; however, with existing data sets, we cannot observe how municipal services are allocated within the jurisdiction. Finally, we note that local governments may expand certain programs in order to combat new social problems associated with rising income inequality, thereby leaving the level of public services unchanged. For example, inequality has been linked to higher rates of violent crime (Fajnzylber, Lederman, \& Loayza, 2002). Cities may hire additional police officers to combat the higher crime rates, resulting in more government spending without net improvements in public safety.

\section{School District Finances}

The second panel of table 1 presents the descriptive statistics for our school district sample. In 1970, the typical district spent $\$ 3,937$ per pupil. By 2000 , this total nearly doubled to $\$ 7,676$ per pupil. The sources of school district revenue changed dramatically over this period. While in 1970, school revenues were evenly split between local property taxes and intergovernmental transfers, local property taxes made up only $35 \%$ of the average school district budget by 2000 .

The changing pattern of revenues in our sample reflects the increasing centralization of $\mathrm{K}-12$ funding over time. States began to supplement local revenues for education services in the mid-twentieth century. At that time, state aid was typically disbursed as a flat grant per pupil, with additional funds provided to poor districts (Hoxby, 2001). In 1965 , the federal government began disbursing school funding through Title I of the Elementary and Secondary School Act (Cascio, et al., 2010). As a result, by 1970, locally raised revenue accounted for only $60 \%$ of school district budgets.

More recently, the use of local revenue sources, even as a supplement to state aid, has been challenged in some states. These objections arise because property taxes allow wealthy districts to raise more revenue than poor districts at the same tax rate, thereby generating an association between the level of wealth in a district and its level of school funding. Starting with the Serrano v. Priest decision in California (1971), a number of state supreme courts have ruled that existing systems of local school finance are unconstitutional. $^{13}$

In response to these legal challenges, states have adopted various plans to equalize school funding across districts

\footnotetext{
${ }^{13}$ Differences in school funding on the basis of local property wealth have been found to violate rights to equal protection under some state constitutions (Briffault, 2006). In other states, local financing violates constitutional provisions requiring that the state provide an adequate elementary and secondary education to all students. Claims under the federal equal protection clause were denied by the Supreme Court in San Antonio Independent School District v. Rodriguez, 411 U.S. 1 (1973).
}

(Hoxby, 2001; Metzler, 2003). The most common approach has been to modify a state's aid formula in order to directly supplement districts with smaller local property tax capacity. Some states also guarantee that districts will be able to raise a certain level of revenue at a given tax rate; the difference between locally raised revenue and the guaranteed level is then made up by the state. Following this wave of reforms, the share of school revenues raised through local property taxes declined from $60 \%$ in 1970 to $35 \%$ in 2000.

\section{Estimating the Relationship Between Income Inequality and Government Activity}

\section{A. Basic Specification for Municipalities}

The relationship between income inequality and public finances can be described by

$$
y_{i t}=\beta(G i n i)_{i t}+\Gamma X_{i t}+R_{i t}+\varepsilon_{i t} \quad \varepsilon_{i t}=\alpha_{i}+v_{i t},
$$

where $i$ indexes a city or town in Census year $t, y$ is a local public finance outcome such as total expenditures, Gini is the Gini coefficient, and the coefficient $\beta$ indicates the estimated effect of income inequality on local finances. $X$ contains a set of time-varying city characteristics, including total population; the share of the population that is black, Hispanic, or over 65 years of age; and median household income. Our preferred specification controls for median income, which in part determines the preferences of the median (decisive) voter for public versus private spending. We also report results that control for mean income, which may be a better measure of the size of a locality's tax base. $R_{i t}$ is a set of time-specific dummy variables for the nine Census regions. $\varepsilon_{i t}$ captures the unobserved determinant of local finances, which depends on a permanent component $\alpha_{i}$ and a transitory component $v_{i t}$.

Pooling four decadal observations from 1970 to 2000 for each area, we estimate

$$
\Delta y_{i t}=\beta(\Delta G i n i)_{i t}+\Gamma \Delta X_{i t}+\Phi\left(R_{i t}-R_{i t-1}\right)+\Delta \mathrm{v}_{i t} .
$$

This first-difference specification absorbs the permanent component of the error term $\left(\alpha_{i}\right)$. The coefficient of interest ( $\beta$ ) indicates the relationship between changes in the Gini coefficient and changes in government revenue or expenditure within a municipality over time, holding constant changes in median income and basic demographics. Decadal changes in the Census region fixed effects $\left(\mathrm{R}_{i t}-\mathrm{R}_{i t-1}\right)$ account for the fact that each Census region has a distinct time trend in levels of government finances during this period; for example, regions in the South started out with low levels of government expenditure and were converging with the rest of the county. For the rest of the paper, we refer to equation (2) as the OLS specification.

The covariates $X$ in equations (1) and (2) need not be exogenous. For example, the fraction of blacks in a city could potentially be affected by changes in inequality and 
therefore be an intermediate outcome. The inclusion of intermediate outcomes could potentially bias our estimates of the impact of inequality on public finances. Section IVA provides a robustness test that excludes race from equation (2). We now turn to the more general issue of household sorting and how instrumental variables can be used to deal with this confounder.

\section{B. Instrumental Variable for Income Inequality}

Equation (2) is not sufficient on its own to establish a causal relationship between income inequality and local government finances. The income distribution may affect government activity through a number of channels: the preferences of local voters, compensatory transfers from the state and federal government, or simply a mechanical relationship between inequality and the size of the local tax base. However, it is also possible that changes in government expenditures could induce shifts in the local income distribution. For instance, an increase in local expenditures may attract wealthy households that prefer more and higherquality public services even at the expense of higher taxes. These high-income arrivals would widen the local income distribution.

To mitigate concerns about this form of reverse causality, we construct an instrumental variable that is correlated with changes in an area's Gini coefficient but is not otherwise associated with changes in local revenues or expenditures. In particular, we predict the income distribution of a municipality or school district at time $t$ based on the area's initial income distribution and national patterns of income growth; we then use the Gini coefficient for this predicted distribution as an instrument for the actual Gini coefficient. In practical terms, we start with the initial (1970) tallies of households by income bin in a locality. We then allow the income level of households in this initial distribution to grow over time according to the actual change in median income by income bin and decade from Census microdata. ${ }^{14}$ In other words, the initial income distribution in an area serves as a set of weights indicating how national income growth likely affects each locality. For example, in the 1980s, the income level of households in the top income bin grew faster than those for the rest of the distribution. The instrument will therefore predict greater changes in the Gini coefficient over the 1980 s in municipalities that started out with a large number of high-income households in 1970.

By freezing the distribution of households across bins in 1970, we foreclose the possibility that richer or poorer households move into a town in search of a given bundle of

\footnotetext{
${ }^{14}$ In particular, we convert the end points of each income bin in 1970 from absolute income levels into percentiles of the income distribution. For example, the first income bin includes households earning up to $\$ 1,000$ in 1970 or up to the 3.7th percentile of the income distribution in that year. We then calculate income growth by decade for the resulting percentile ranges. Results are qualitatively similar when we allow changes in median income by bin and decade to vary by region.
}

Figure 1.-First-Stage Regression: Relationship Between Actual and Synthetic Gini Coefficients at the Municipal Level, 1970-2000
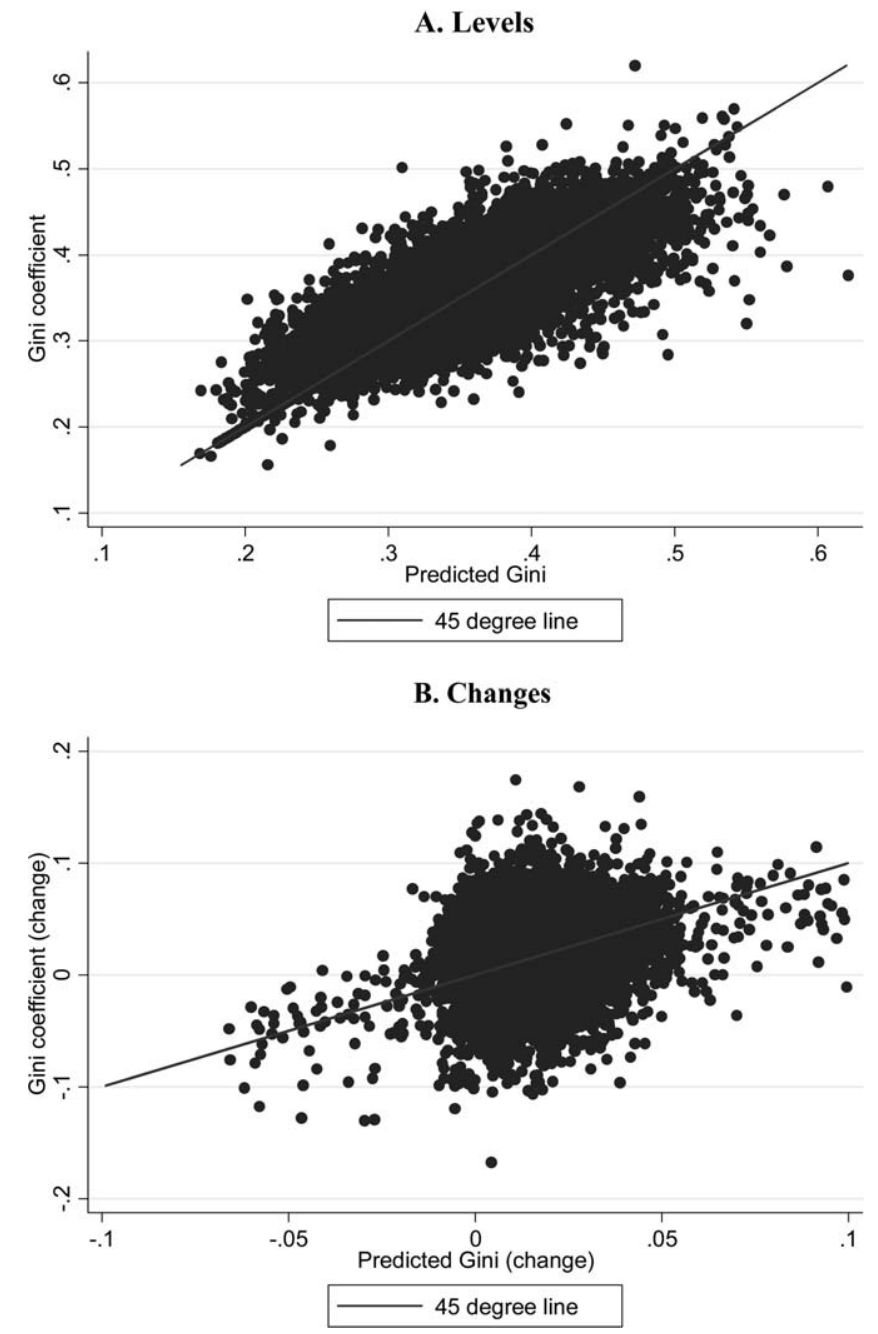

Panel A: Each point in the scatter diagram represents a municipality's actual and predicted Gini coefficients. Gini coefficients are calculated using the income bins from Census reports and the median income of each bin from Census microdata. The computation of predicted Gini coefficients is described in section IIIB.

tion IIIB.
Panel B: Each point in the scatter diagram represents the residual change in a municipality's actual and predicted Gini coefficients over a decade after controlling for changes in population, share of black and Hispanic population, median income, share of individuals older than 65 and regional trends.

public goods. It is important to note that our instrument cannot address the possibility that rising inequality due to higher incomes at the top end of the income distribution mechanically increases government expenditures through an expansion of the tax base. We consider this possibility below in a series of robustness tests.

We present the first-stage relationship between the actual and predicted Gini coefficients figure 1 in both level and changes. We find a strong positive relationship between the two measures, suggesting that much of the change in local income distributions from 1970 to 2000 was driven by trends in income growth rather than by in- and out-mobility of households from the top or bottom of the income distribution. The coefficient for this first-stage relationship at the municipality level is $0.746(\mathrm{SE}=0.030)$ and is reported in table 4. The F-statistic on the relationship between the 
Table 2.-OLS Estimates, Relationship Between Municipality Characteristics and Revenue/Expenditures PER Capita, 1970-2000

\begin{tabular}{|c|c|c|c|c|}
\hline & \multicolumn{2}{|c|}{ General Revenue } & \multicolumn{2}{|c|}{ General Expenditure } \\
\hline & Full Sample & Drop Outliers & Full Sample & Drop Outliers \\
\hline \multirow[t]{2}{*}{ Gini coefficient } & $460.8 * *$ & $382.4 * * *$ & $532.9 * *$ & $313.5^{* * *}$ \\
\hline & $(208.9)$ & $(106.0)$ & $(208.9)$ & $(117.8)$ \\
\hline \multirow[t]{2}{*}{$\ln ($ median income $)$} & $219.7 * * *$ & $182.1 * * *$ & $254.4 * * *$ & $193.8 * * *$ \\
\hline & (36.1) & (25.9) & (40.9) & (26.2) \\
\hline \multirow[t]{2}{*}{$\ln$ (population) } & $-211.7 * * *$ & $-121.5^{* * *}$ & $-215.7 * * *$ & $-127.4^{* * * *}$ \\
\hline & (33.7) & (15.1) & (34.9) & (15.8) \\
\hline \multirow[t]{2}{*}{ Share black } & $-152.3^{*}$ & $-90.9 *$ & -146.4 & -79.2 \\
\hline & (85.3) & $(50.4)$ & (91.4) & $(57.7)$ \\
\hline \multirow[t]{2}{*}{ Share Hispanic } & $-152.3^{*}$ & $-151.9 * * *$ & -54.3 & $-168.5^{* *}$ \\
\hline & (88.8) & $(56.7)$ & $(135.7)$ & $(65.9)$ \\
\hline \multirow[t]{2}{*}{ Share 65 years or more } & -334.7 & -87.0 & -190.5 & -58.3 \\
\hline & $(204.8)$ & $(122.8)$ & $(228.5)$ & $(125.8)$ \\
\hline \multirow[t]{2}{*}{ Constant } & 73.17 & 4.362 & 38.9 & 77.3 \\
\hline & $(114.8)$ & $(55.4)$ & (104.9) & (75.9) \\
\hline$N$ & 10,133 & 9,735 & 10,133 & 9,735 \\
\hline
\end{tabular}

Sample includes all municipalities in the Census years 1970 through 2000 with 2,500 residents that were not responsible for education services in 1970. Cells report the estimated coefficients from equation (2). Standard errors in parentheses and are clustered by municipality. Columns 2 and 4 drop municipalities with the largest and smallest $1 \%$ of changes in either the Gini coefficient or the municipal revenues by decade.

Coefficient statistically significant at $* * * 1 \%, * * 5 \%$, and $* 10 \%$.

actual and synthetic Gini coefficients is 975.77 , surpassing the conventional threshold for a strong instrument by two orders of magnitude.

\section{Additional Specification for School Districts}

Analyzing the relationship between income inequality and school district revenues requires additional care because of substantial changes in the organization of school finance over this period. In particular, we want to allow for the possibility that an increase in income inequality may have different effects in states with and without school finance equalization plans. Under a state equalization plan, districts that experience rising income inequality due to income growth for the rich may be heavily taxed, whereas districts with inequality driven by falling incomes among the poor may be heavily subsidized.

We define a school finance reform (SFR) indicator variable equal to 1 in the fourteen states whose systems of school finance were declared unconstitutional by the state supreme court between 1970 and 2000. ${ }^{15}$ Equation (3) interacts the state reform variable with changes in the school district-level Gini coefficient. We estimate

$$
\begin{aligned}
\Delta y_{i t}= & \theta(S F R)_{i t}+\beta_{1}(\Delta G i n i)_{i t}+\beta_{2}(\Delta G i n i \times S F R)_{i t} \\
& +\Gamma \Delta X_{i t}+\Phi\left(R_{i t}-R_{i t-1}\right)+v_{i t},
\end{aligned}
$$

where $i$ indexes school districts and $t$ indicates the Census decade $(t=1970,2000)$. Note that for this specification, we consider a single long-run change in school expenditures from 1970 to 2000 in each district in order to allow the reforms of the 1970s and 1980s time to take hold. The coefficient $\beta_{1}$ summarizes the average relationship between changes in income inequality and changes in revenues or

\footnotetext{
${ }^{15}$ We rely on Card and Payne's (2002) taxonomy of school finance cases as updated by Baicker and Gordon (2006).
}

expenditures per pupil. The coefficient $\beta_{2}$ tests whether this relationship is different in states that fell under court order to reform their system of school finance by 2000 . We also allow the effect of district-level median income to vary according to a state's school finance regime. States that did not face a court order over this period may have reformed their school finance systems preemptively in order to avoid the threat of litigation (Metzler, 2003). In this case, states with and without court-ordered reforms will respond equivalently to changes in inequality, leading the coefficients on the interaction term $\left(\beta_{2}\right)$ to be indistinguishable from 0 .

\section{Results}

\section{A. Impact of Income Inequality on Municipalities}

We start our empirical analysis by considering the relationship between income inequality and government activity at the municipality level. Table 2 presents OLS estimates of equation (2), which evaluates the relationship between changes in income inequality and changes in government revenue or expenditure within cities and towns over time. We report results for the full sample and a modified sample that excludes outliers. In particular, we drop the municipalities with the largest $1 \%$ and smallest $1 \%$ of changes in either the Gini coefficient or in municipal revenues by decade. In both cases, we find that an increase in inequality leads to modest growth in municipal revenues and expenditures. The coefficients imply that a 5 point increase in the Gini coefficient, the average change in the Gini over this period, is associated with a $\$ 19$ to $\$ 27$ increase in expenditures per capita. ${ }^{16}$ Table 2 also reports coefficients on the other municipality characteristics

\footnotetext{
${ }^{16}$ We find the $\$ 27$ number by multiplying the general expenditure point estimate in table 2 (\$532.9) by the change in Gini coefficient $(0.05)$.
} 
Table 3.-OLS Estimates, Relationship Between Income InEQuality and Components of Municipal Revenue and Expenditures Per CAPita, 1970-2000

\begin{tabular}{|c|c|c|c|c|c|c|}
\hline & \multicolumn{6}{|c|}{ Revenue } \\
\hline & $\begin{array}{l}\text { General } \\
\text { Revenue }\end{array}$ & $\begin{array}{l}\text { Property } \\
\text { Tax }\end{array}$ & $\begin{array}{l}\text { Intergovernmental } \\
\text { Transfers }\end{array}$ & $\begin{array}{c}\text { Direct } \\
\text { Charges }\end{array}$ & $\begin{array}{c}\text { Sales } \\
\text { Tax }\end{array}$ & $\begin{array}{c}\text { Other } \\
\text { Revenue }\end{array}$ \\
\hline & $\begin{array}{l}382.4 * * * \\
{[106.0]}\end{array}$ & $\begin{array}{l}120.6^{* * * *} \\
{[25.2]}\end{array}$ & $\begin{array}{c}26.9 \\
{[54.1]}\end{array}$ & $\begin{array}{l}104.2 * * \\
{[45.4]}\end{array}$ & $\begin{array}{l}44.8 * * \\
{[19.9]}\end{array}$ & $\begin{array}{c}-0.86 \\
{[50.3]}\end{array}$ \\
\hline & \multicolumn{6}{|c|}{ Expenditures } \\
\hline $\begin{array}{l}\text { General } \\
\text { Expenditure }\end{array}$ & Police & Fire & Highways & $\begin{array}{l}\text { Public } \\
\text { Welfare }\end{array}$ & $\begin{array}{l}\text { Health \& } \\
\text { Hospitals }\end{array}$ & $\begin{array}{c}\text { Other } \\
\text { Expenditures }\end{array}$ \\
\hline $\begin{array}{l}313.5^{* * * *} \\
{[117.8]}\end{array}$ & $\begin{array}{l}87.2 * * * \\
{[19.3]}\end{array}$ & $\begin{array}{l}41.4^{* * * *} \\
{[9.7]}\end{array}$ & $\begin{array}{l}54.4 * * * \\
{[17.3]}\end{array}$ & $\begin{array}{c}-0.22 \\
{[0.98]}\end{array}$ & $\begin{array}{l}-0.50 \\
{[11.3]}\end{array}$ & $\begin{array}{c}131.0 \\
{[108.1]}\end{array}$ \\
\hline
\end{tabular}

changes in either the Gini coefficient or Census years 1970 to 2000 with 2,500 residents that were not responsible for education services in 1970 . We also drop municipalities with the largest and smallest $1 \%$ of and are clustered by municipality. Coefficient statistically significant at $* * * 1 \%, * * 5 \%$, and $* 10 \%$.

Table 4.- - IV Estimates, Relationship Between Income Inequality and Municipal Revenue and Expenditure Per Capita, 1970-2000

\begin{tabular}{|c|c|c|c|c|c|c|}
\hline \multirow{3}{*}{$\begin{array}{l}\text { First Stage } \\
\text { Estimate }\end{array}$} & \multicolumn{6}{|c|}{ IV Estimates: Revenue } \\
\hline & General & Property & Intergovernmental & Direct & Sales & Other \\
\hline & Revenue & Tax & Transfers & Charges & $\operatorname{Tax}$ & Revenue \\
\hline \multirow{3}{*}{$\begin{array}{l}0.746^{* * * *} \\
{[0.03]}\end{array}$} & $1768 * * *$ & $496.4 * * *$ & $596.9 * * *$ & $327.7 * *$ & $125.1^{*}$ & 56.8 \\
\hline & {$[389.7]$} & [119.5] & {$[169.2]$} & {$[165.1]$} & {$[69.4]$} & [181.4] \\
\hline & \multicolumn{6}{|c|}{ IV Estimates: Expenditures } \\
\hline General & & & & Public & Health \& & Other \\
\hline Expenditure & Police & Fire & Highways & Welfare & Hospitals & Expenditures \\
\hline $1345^{* * *}$ & $269.8 * * *$ & $137.7 * * *$ & -31.14 & 4.78 & 32.7 & $1,399 * * *$ \\
\hline$[402.0]$ & {$[85.3]$} & {$[45.7]$} & {$[66.08]$} & {$[3.00]$} & [39.6] & [360.2] \\
\hline
\end{tabular}

included in the vector of covariates. We find that municipalities that were expanding in total population or had a growing black or Hispanic population share reduced public expenditures over this period, while municipalities with rising median income increased public expenditures. A $10 \%$ increase in median income among town residents is associated with a $\$ 20$ to $\$ 24$ increase in expenditures per capita. Although excluding outliers reduces the point estimates somewhat, it also cuts the standard errors in half, notably increasing the statistical power of the estimated relationship. We continue to exclude these outliers throughout the paper.

Table 3 investigates the relationship between changes in the income distribution and changes in subcomponents of municipality revenues and expenditures. If inequality heightens crime, the extra spending associated with an increase in inequality could be entirely dedicated to an expanded police force. Instead, we find that a 5 point increase in the Gini coefficient leads to a $\$ 4$ increase in per capita police spending (out of total additional expenditures of $\$ 19$ ); the remainder is spent on other "productive" public services, including fire protection and local roads. Income inequality has no relationship with spending on public welfare and health and hospitals; however, together, these categories represent less than $5 \%$ of the typical municipal budget.

Table 3 also demonstrates that the revenues required to fund these additional expenditures are collected using a range of local tax instruments, including property taxes, sales taxes, and direct charges for services. The one revenue category that is not associated with a widening of the income distribution is federal and state transfers. This result is not surprising because the majority of state transfers to local governments are provided to school districts, which are examined in the next section, and because state transfers to municipalities are based on formulas that often do not take into account the local income distribution.

Thus far, we have documented that a widening of the income distribution is associated with growth in municipal revenues and expenditures. Yet the OLS results cannot rule out a reverse relationship, whereby local spending attracts households at the lower or upper end of the income distribution. Table 4 contains results from our instrumental variables analysis, in which we instrument for changes in the actual Gini coefficient with changes in the Gini coefficient for the predicted income distribution in an area. Most of the IV coefficients are positive, statistically significant, and, if anything, larger than their OLS counterparts. 
Table 5.-Alternative IV Specifications, Relationship Between Income Inequality and Municipal Revenue Per Capita, 1970-2000

\begin{tabular}{|c|c|c|}
\hline & $\begin{array}{l}\text { General } \\
\text { Revenue } \\
\end{array}$ & $\begin{array}{c}\text { General } \\
\text { Expenditures } \\
\end{array}$ \\
\hline & IV & IV \\
\hline 1. Baseline & $\begin{array}{c}1,768 * * * \\
{[389.7]}\end{array}$ & $\begin{array}{c}1,345^{* * * *} \\
{[402.0]}\end{array}$ \\
\hline 2. Five education categories & $\begin{array}{c}858.1 \\
{[767.7]}\end{array}$ & $\begin{array}{l}1,106 \\
{[856.0]}\end{array}$ \\
\hline $\begin{array}{l}\text { 3. Drop } \ln \text { (median income); } \\
\text { add } \ln (\text { mean income })\end{array}$ & $\begin{array}{l}1,721 * * * \\
{[454.4]}\end{array}$ & $\begin{array}{l}1,143^{*} \\
{[680.7]}\end{array}$ \\
\hline $\begin{array}{l}\text { 4. Fifth-order polynomial, } \\
\ln (\text { median income) }\end{array}$ & $\begin{array}{l}378.5 \\
{[746.3]}\end{array}$ & $\begin{array}{c}855.7 \\
{[815.3]}\end{array}$ \\
\hline 5. Initial (1970) Gini & $\begin{array}{c}999.1 \\
{[624.3]}\end{array}$ & $\begin{array}{c}971.1 \\
{[833.5]}\end{array}$ \\
\hline 6. With state time trends & $\begin{array}{c}1,747 * * * \\
{[396.4]}\end{array}$ & $\begin{array}{c}1,426 * * * \\
{[413.1]}\end{array}$ \\
\hline 7. Include outliers & $\begin{array}{l}997.3 \\
{[642.7]}\end{array}$ & $\begin{array}{l}1,144 \\
{[699.1]}\end{array}$ \\
\hline $\begin{array}{l}\text { 8. In levels with municipality } \\
\text { fixed effect }\end{array}$ & $\begin{array}{c}4,198 * * * \\
{[824.6]}\end{array}$ & $\begin{array}{c}3,105 * * * \\
{[913.2]}\end{array}$ \\
\hline 9. Without race controls & $\begin{array}{c}953.3 \\
{[638.4]}\end{array}$ & $\begin{array}{l}1,106 \\
{[692.1]}\end{array}$ \\
\hline
\end{tabular}

Sample includes all municipalities in the Census years 1970 through 2000 with 2,500 residents that were not responsible for education services in 1970. We also drop municipalities with the largest and smallest $1 \%$ of changes in either the Gini coefficient or the municipal revenues by decade $(N=9,735)$. Each cell reports the coefficient from a different version of equation (2). Standard errors in parentheses and are clustered by municiplity. The first row repeats the baseline coefficient from to 2 . Rows $2-10$ include an additional set of explater include an additional set of explanatory variables as indicated. Coefficient statistically significant at

If our OLS estimates were driven by reverse causalityfor example, because the rich are attracted to towns with generous public services-we would expect the IV coefficients to be smaller than OLS. The fact that the IV estimates are larger than OLS suggests that the instrumental variables procedure may instead be correcting for measurement error, which can bias estimates toward 0. By these estimates, a 5 point increase in the Gini coefficient leads to an $\$ 88$ increase in expenditures per capita. From 1970 to 2000 , the average municipality experienced a $\$ 408$ increase in revenues per capita. The widening of the income distribution can thus explain $22 \%$ of the growth in the size of local governments from 1970 to 2000 (=88/408). Overall, the pattern of both OLS and IV results suggests that income inequality neither reduces the demand for municipal goods and services nor limits residents' ability to pay for them.

Table 5 compares the baseline IV relationship with results from a number of alternate specifications. For comparison, we reproduce the main results in row 1. Overall, we find that the Gini coefficient always has a positive effect on local revenues and expenditures, although in some cases, the estimated coefficient is no longer statistically different from 0 . It is notable that even after controlling for many aspects of the local population, we do not find the negative association between income inequality and public spending posited in the existing literature.

The first set of alternative specifications explores the effect of rising incomes at the top end of the income distribution, which, by increasing both income inequality and the size of the tax base, can create a mechanical relationship between the two variables of interest. For example, if a por- tion of extra income earned by the rich is used to improve local real estate, the property tax base could increase in value, allowing the municipality to raise more revenue at the same tax rate. We measure rising inequality at the top end of the income distribution in three ways: first, we include indicators for the educational attainment of household heads in five categories; second, we control for mean, rather than median, household income; and third, we include a fifth-order polynomial in the logarithm of median income. In all cases, the relationship between the Gini coefficient and municipal revenue or expenditure remains positive. For some specifications, the coefficient is cut in half or more. We conclude that some portion of the estimated relationship is likely driven by the effect of rising top-end inequality on the size of the local tax base. ${ }^{17}$

Our main results emphasize how changes in an area's income distribution affect local revenues and expenditures. However, some municipalities, especially those in the South, have a long history of inequality. Long-standing patterns of inequality affect the construction of our instrumental variable, which is based on household composition in a locality as of 1970, but could also have an independent influence on both the level and trajectory of government activity in an area. The fifth row of table 5 adds the initial (1970) Gini coefficient alongside changes in the Gini coefficient by decade. We continue to find that a widening of the income distribution is positively associated with municipal revenues. In contrast, places that started out with high levels of inequality in 1970 experience small declines in revenue per capita, especially revenue from property taxes, over the next few decades (not shown). Row 6 controls for statelevel time trends rather than just regional trends, and the coefficients are still large and statistically significant.

The final rows of table 5 consider additional robustness tests. Including outliers or dropping the race and ethnicity controls preserves the positive relationship between income inequality and local government activity, but the coefficients of interest are no longer statistically significant. We also try estimating equation (1) with municipality fixed effects instead of first differencing the data, as in equation (2). In this case, we find an even larger relationship between the Gini coefficient and municipal revenues.

These results suggest that the relationship between income inequality and local government activity is not entirely an artifact of top-end income growth, nor does it only reflect the effect of long-standing differences in inequality.

\footnotetext{
${ }^{17}$ We also explore the robustness of our results to flexibly controlling for the initial share of households in each of fifteen income bins underlying the construction of the instrument. In particular, we are interested in whether the estimated effect of changes in the Gini coefficient is driven by the share of households in the top few income bins. Although these shares are nearly colinear with the instrument itself, we can separately include them, alongside the Gini coefficient itself, in the OLS regression. The effect of the Gini coefficient is qualitatively similar when we include these additional controls (for general revenue, coefficient $=388.3, \mathrm{SE}=$ 222.0; for general expenditures, coefficient $=497.5, \mathrm{SE}=219.7$ ).
} 
Table 6.-OLS Estimates, Relationship between Racial Fractionalization and Municipal Revenue and Expenditures Per Capita, 1970-2000

\begin{tabular}{|c|c|c|c|c|c|c|}
\hline \multirow{3}{*}{$\begin{array}{l}\text { General } \\
\text { Revenue }\end{array}$} & \multicolumn{6}{|c|}{ Revenue } \\
\hline & Property & Inter & ntal & Direct & Sales & Other \\
\hline & Tax & & & Charges & Tax & Revenue \\
\hline \multirow{3}{*}{$\begin{array}{l}123.4 * * * \\
{[43.98]}\end{array}$} & $60.12 * * *$ & & & -8.28 & $37.86 * * *$ & -10.81 \\
\hline & [11.73] & & & [18.27] & {$[9.88]$} & [21.52] \\
\hline & \multicolumn{6}{|c|}{ Expenditures } \\
\hline General & & & & Public & Health \& & Other \\
\hline Expenditures & Police & Fire & Highways & Welfare & Hospitals & Expenditures \\
\hline $91.27 *$ & $39.21 * * *$ & $13.09 * * *$ & 7.19 & 0.46 & 8.74 & 15.77 \\
\hline [49.15] & {$[9.04]$} & {$[4.84]$} & [6.92] & {$[0.51]$} & [6.01] & [44.91] \\
\hline
\end{tabular}

\section{B. Impact of Change in Racial Heterogeneity on Municipalities}

This section examines the effect of racial fractionalization, another form of local heterogeneity, on municipal budgets. Alesina et al. (1999) argue that although cities with a racially diverse population spend more per resident, they devote a smaller share of their budget to "productive" public goods, such as roads, sewers, and trash collection. In table 6 , we reestimate equation (2), replacing the Gini coefficient with an index of racial/ethnic fractionalization. Our index is based on four racial/ethnic categories: white, nonHispanics; black, non-Hispanics; Hispanics; and other races (which include Asians, Pacific Islanders, and American Indians). ${ }^{18}$ For this specification, we also omit the separate measures of black and Hispanic population share. We improve the methodology used in Alesina et al. (1999) by using a panel of cities from 1970 to 2000 rather than a single cross-section in 1990 and by extending the analysis to municipalities with fewer than 25,000 residents.

As in Alesina et al. (1999), we find that an increase in racial heterogeneity is associated with larger municipal expenditures and that a portion of this increase is due to higher police spending. However, we also find large positive effects on fire protection and health and hospital spending. Because spending on roads fails to keep pace with the overall increase in expenditures, the share of the budget dedicated to roads does fall, which Alesina et al. (1999) interpret as a decline in the share of revenue dedicated to productive public goods. We contend that the interpretation of these patterns are extremely sensitive to the classification of municipal spending into "productive" versus "nonproductive" public goods. It is reasonable to believe that spending on fire protection and public hospitals is equally as productive as spending on roads and, conversely, that spending on roads is equally susceptible to corruption for patronage purposes.

\footnotetext{
${ }^{18}$ The racial fractionalization index is defined as $1-\Sigma_{\mathrm{i}}$ (residents of race or ethnicity $)^{2}{ }^{2}$ Separate counts of Asian and Pacific Islanders do not exist at the municipal level in 1970 or 1980.
}

Table 7.- OLS and IV Estimates, Relationship between Income Inequality and School District Revenue And Expenditure Per CAPITA, 1970-2000

\begin{tabular}{lccc}
\hline \hline & Total Spending & Property Tax & State Transfers \\
\hline OLS & 1,007 & $2,565^{* * * *}$ & $-2,754 * * *$ \\
& {$[656,3]$} & {$[704.4]$} & {$[591.8]$} \\
First-stage IV & & & \\
$0.745^{* * *}$ & 3,783 & $15,103^{* * *}$ & $-20,478 * * *$ \\
{$[0.04]$} & {$[2857]$} & {$[3880]$} & {$[2169]$} \\
\hline \multicolumn{2}{l}{ Sample includes school districts in Census years $1970-2000$. We drop school districts with the largest }
\end{tabular}

Sample includes school districts in Census years 1970-2000. We drop school districts with the largest and smallest $1 \%$ of changes in either the Gini coefficient or the municipal revenues by decade $(N=$ Cells report the estimated coefficient on the change in the Gini coefficient from equation (2). The instrument for the actual Gini coefficient is based on a "synthetic" version of the local income distribution. see section IIIB for details. Coefficient statistically significant at $* * * 1 \%, * * 5 \%$, and $* 10 \%$.

On the revenue side, we confirm Alesina et al.'s (1999) finding that racial heterogeneity is associated with an increase in intergovernmental transfers. However, we dispute the interpretation that racially diverse cities are unwilling to raise their own revenue and therefore need to be subsidized by the state "to compensate ... [for] the difficulties ... in directing local resources to the supply of public goods" (p. 1266). Instead, we find that an increase in racial diversity is also associated with an increase in own-source revenue collection as well, including both revenue from property taxes and sales taxes.

\section{Impact of Income Inequality on School Districts}

Turning to school districts, we begin in table 7 by estimating the baseline specification, equation (2), which relates decadal changes in income inequality to changes in government activity. As for municipalities above, we find here that an increase in income inequality among residents of a school district is associated with rising expenditures per pupil. However, the relationship between income inequality and total expenditures per pupil is small. According to our IV estimate, a 3.4 point increase in the Gini coefficient, the average increase at the school district level from 1970 to 2000, would result in expenditures of $\$ 129$ per pupil over those four decades. Recall that school district expenditures per pupil are nearly an order of magnitude lar- 


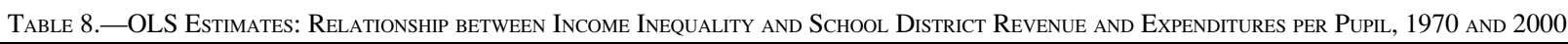

\begin{tabular}{|c|c|c|c|c|c|c|}
\hline & \multicolumn{3}{|c|}{ Panel 1} & \multicolumn{3}{|c|}{ Panel 2} \\
\hline & Total Spending & Property Tax & State Transfers & Total Spending & Property Tax & State Transfers \\
\hline \multirow[t]{2}{*}{ Court order (SFR) } & $427.7 * *$ & 104.0 & 396.2 & 2,922 & $-9,328$ & $16,860 * * *$ \\
\hline & {$[179.3]$} & [180.7] & [274.2] & {$[3,389]$} & [5980] & [4856] \\
\hline \multirow[t]{2}{*}{ Gini coefficient } & $3,212 * *$ & $6,792 * * *$ & $-6,568 * * *$ & $3,453 *$ & $5,027 * *$ & $-3,829 * *$ \\
\hline & {$[1,553]$} & {$[1,530]$} & {$[1,607]$} & {$[1,665]$} & {$[1,874]$} & {$[1,622]$} \\
\hline \multirow[t]{2}{*}{ Gini $\times$ SFR } & & & & 244.9 & $4,086^{*}$ & $-5,257^{*}$ \\
\hline & & & & {$[2,335]$} & {$[2,246]$} & {$[2,940]$} \\
\hline \multirow[t]{2}{*}{$\ln ($ median income $)$} & $1,061 * * *$ & $2,009^{* * *}$ & $-1,792 * * *$ & $1,197 * * *$ & $1,629 * * *$ & $-1,080^{*}$ \\
\hline & {$[241.8]$} & {$[406.3]$} & [459.6] & {$[221.5]$} & {$[535.5]$} & [575.9] \\
\hline \multirow[t]{2}{*}{$\ln ($ median $) \times$ SFR } & & & & -240 & 740.4 & $-1,354 * * *$ \\
\hline & & & & [254.6] & [498.0] & [390.0] \\
\hline
\end{tabular}

school districts). Cells report the estimated coefficients of equation (3). SFR is an indicator variable equal to 1 in the year 2000 for the fourteen states whose systems of school finance were deemed unconstitutional by the state supreme court. Standard errors in parentheses and are clustered by school district. Coefficient statistically significant at $* * * 1 \%$, **5\%, and $* 10 \%$.

ger than municipal expenditures per resident; therefore, this increase would represent only $1.5 \%$ of the typical school budget in the year 2000 .

The small effect of inequality on total school resources in column 1 masks countervailing trends for the two main sources of revenue. According to the IV estimates, a 3.4 point increase in the Gini is associated with a $\$ 514$ increase in property tax revenue per pupil (column 2) and a corresponding $\$ 697$ decline in state transfers (column 3). That is, in both municipalities and school districts, a widening income distribution is associated with more own-source revenue collection. However, rising inequality is also associated with a compensating decline in state transfers to school districts, a source that accounted for a majority of school revenues over this period. We then test whether this pattern is stronger in states with systems of school finance equalization in place that may have undermined the association between local income distribution and local revenue collection.

Table 8 presents results from our estimation of equation (3), which allows the effect of income inequality on school district finances to vary with a state's system of school finance. For this specification, we report OLS coefficients because the instrument is not sufficiently powerful to explain changes in inequality over this thirty-year interval. ${ }^{19}$ The first panel replicates the basic specification over this thirtyyear period (comparable to table 7); in the second panel, we allow the relationships between changes in a district's level of income inequality and median income to differ in states with and without court-ordered school finance reform.

The first row of table 8 shows that states under court order to reform their system of school finance provide a higher level of state transfers per pupil (see also Card \& Payne, 2002). By 2000, the average district under court

\footnotetext{
19 The first-stage coefficient on the decadal specification at the school district level is $0.745(\mathrm{SE}=0.04)$, whereas the coefficient on the first stage for the long-run specification is $0.213(\mathrm{SE}=0.115)$. As is common with weak instruments, the second-stage coefficients are large and imprecise in the long-run specification, and hence table 8 reports only the OLS estimates.
}

order received an additional $\$ 396$ of state funding per pupil, which translates into $\$ 427$ of additional spending per pupil. As in table 7, we document that school districts in which the income distribution widened between 1970 and 2000 raise more revenue per pupil from property taxation, which is entirely offset by a corresponding decline in state transfers. Panel 2 demonstrates that the relationship between income inequality and school expenditures is mediated by court supervision of a state's system of school finance. In districts whose state system of school finance is not under court supervision, the increase in property taxes associated with rising inequality is only partially offset by a decline in state transfers, such that a 3.4 point increase in the Gini would lead to a $\$ 116$ increase in total resources per pupil. However, in states with strong equalization programs, the excess taxing capacity that accompanies rising income inequality is completely offset by reductions in state aid.

Table 8 also reports the relationship between educational expenditures and the median income of a school district's residents. Not surprisingly, wealthier districts spend more on education per pupil. On average, a 10\% increase in median income is associated with a increase of in $\$ 106$ per pupil expenditures. This relationship is driven by an increase in locally raised revenue. In all states, districts with higher median incomes receive fewer transfers from the state. The reduction in state funds more than doubles in states under court order to equalize their systems of school finance.

\section{Conclusion}

The income distribution in the United States widened greatly from 1970 to 2000 . We use variation in income dispersion at the local level to examine the relationship between income inequality and the size of the public sector. Contrary to models that emphasize disagreements between residents of heterogeneous societies over the optimal level of public expenditures, we find that rising income inequality is associated with larger increases in tax revenues and faster growth in public expenditures at municipality and school district levels. 
Revenues and expenditures per resident increased in nearly all communities over this period. Our best causal estimates suggest that a 4 to 5 point increase in the Gini coefficient, around the magnitude of change experienced by the average locality from 1970 to 2000 , leads to increase in municipal expenditures of $\$ 88$ per resident to cover services like police and fire protection and infrastructure maintenance and an increase in locally raised school expenditures of $\$ 514$ per pupil. Within school districts, much of the rise in own-source revenue accompanying an increase in inequality was offset by a decline in state transfers, with the size of the offset doubling in states under court order to equalize school funding across districts. By our estimate, the widening of the income distribution can explain around $20 \%$ of the growth in municipal expenditures over the period.

We conclude by noting that although income inequality is associated with greater public expenditures, it is not clear that additional funds necessarily translate into a larger quantity or higher quality of public goods. Furthermore, the incidence of local taxation and the distribution of local services need not be progressive and likely varies substantially across governmental units. Hence, we stop short of claiming that local government activity wholly or partially compensates for the potential social ills associated with income inequality. However, given the empirical patterns documented here, we argue that it is unlikely that the social ills correlated with inequality are due to a weakening of the public sector.

\section{REFERENCES}

Aaron, Henry J., "A New View of Property Tax Incidence," American Economic Review 64 (1974), 212-221.

Alesina, Alberto, Reza Baqir, and William Easterly, "Public Goods and Ethnic Divisions," Quarterly Journal of Economics 114 (1999), $1243-1284$

Alesina, Alberto, and Dani Rodrik, "Distributive Politics and Economic Growth," Quarterly Journal of Economics 109 (1994), 465-490.

Autor, David, Lawrence Katz, and Melissa Kearney, "The Polarization of the U.S. Labor Market,” American Economic Review 96 (2006), 189-194.

Baicker, Katherine, and Nora Gordon, "The Effect of State Education Finance Reform on Total Local Resources," Journal of Public Economics 90 (2006), 1519-1535.

Benabou, Roland, "Heterogeneity, Stratification, and Growth: Macroeconomic Implications of Community Structure and School Finance," American Economic Review 86 (1996), 584-609.

"Unequal Societies: Income Distribution and the Social Contract," American Economic Review 90 (2000), 96-129.

Blau, Francine, and Lawrence Kahn "International Differences in Male Wage Inequality: Institutions versus Market Forces," Journal of Political Economy 104 (1996), 791-837.

Boix, Carles, and Posner, Daniel N., "Social Capital: Explaining its Origin and Effects on Governmental Performance," British Journal of Political Science 28 (1998), 686-693.

Briffault, Richard, "Home Rule and Local Political Innovation," Journal of Law and Politics 22:1 (2006), 1-32.

Card, David, and A. Abigail Payne, "School Finance Reform, the Distribution of School Spending, and the Distribution of Student Test Scores," Journal of Public Economics 83 (2002), 49-82.

Cascio, Elizabeth, Nora Gordon, Ethan Lewis, and Sarah Reber, "Paying for Progress: Conditional Grants and the Desegregation of Southern Schools," Quarterly Journal of Economics 125 (2010), 445482
Chernick, Howard, "On the Determinants of Subnational Tax Progressivity in the U.S.," National Tax Journal 58 (2005), 93-112.

Corcoran, Sean P., and William N. Evans, "Income Inequality, the Median Voter, and the Support for Public Education," NBER working paper 16097 (2010).

Costa, Dora L., and Matthew E. Kahn, "Understanding the American Decline in Social Capital, 1952-1998," Kyklos 56 (2003), 17-46.

Cutler, David M., Douglas W. Elmendorf, and Richard Zeckhauser "Demographic Characteristics and the Public Bundle," Public Finance 48 (1993), 178-198.

Deaton, Angus, and Darren Lubotsky, "Mortality, Inequality and Race in American Cities and States," Social Science and Medicine 56 (2003), 1139-1153.

Epple, Dennis, and Richard E. Romano, "Ends Against the Middle: Determining Public Service Provision When There Are Private Alternatives," Journal of Public Economics 62 (1996), 297-325.

Fajnzylber, Pablo, Daniel Lederman, and Norman Loayza, "Inequality and Violent Crime," Journal of Law and Economics 45 (2002), 139.

Galor, Oded, Omer Moav, and Dietrich Vollrath, "Land Inequality, the Emergence of Human Capital Promoting Institutions and the Great Divergence," Review of Economic Studies 76 (2009), 143-179.

Goldin, Claudia, and Lawrence F. Katz, "Human Capital and Social Capital: The Rise of Secondary Schooling in America, 1910-1940," Journal of Interdisciplinary History 26 (1999), 683-723.

Hamilton, Bruce W., "Capitalization of Intrajurisdictional Differences in Local Tax Prices," American Economic Review 66 (1976), 743 753.

Hopkins, Daniel J., "The Diversity Discount: When Increasing Ethnic and Racial Diversity Prevents Tax Increases," Journal of Politics 71 (2009), 160-177.

Hoxby, Caroline M., "All School Finance Equalizations Are Not Created Equal," Quarterly Journal of Economics 116 (2001), 1189-1231.

Kawachi, Ichiro, Bruce P. Kennedy, Kimberly Lochner, and Deborah Prothrow-Smith, "Social Capital, Income Inequality, and Mortality," American Journal of Public Health 87 (1997), 1491-1498.

Kennedy, Bruce P., Ichiro Kawachi, Deborah Prothrow-Stith, Kimberly Lochner, and Vanita Gupta, "Social Capital, Income Inequality, and Firearm Violent Crime," Social Science Medicine 47 (1998), $7-17$.

Lee, David, "Wage Inequality in the United States during the 1980s: Rising Dispersion or Falling Minimum Wage?" Quarterly Journal of Economics 114 (1999), 977-1023.

Lindert, Peter H., "The Rise in Social Spending, 1880-1930," Explorations in Economic History 31 (1994), 1-37.

"What Limits Social Spending?" Explorations in Economic History 33 (1996), 1-34.

Meltzer, Allan H., and Scott F. Richard, "A Rational Theory of the Size of Government," Journal of Political Economy 89 (1981), 914-927.

Metzler, Jeffrey, "Inequitable Equilibrium: School Finance in the United States," Indiana Law Review 36 (2003), 561-608.

Mieszkowski, Peter M., "The Property Tax: An Excise Tax or a Profits Tax?" Journal of Public Economics 1 (1972), 13-96.

Moene, Karl O., and Michael Wallerstein, "Social Democracy as a Development Strategy," In Pranab Bardhan, Samuel Bowles, and Michael Wallerstein, eds., Globalization and Egalitarian Redistribution (Princeton, NJ: Princeton University Press, 2005).

Musgrave, Richard A., "Is a Property Tax on Housing Regressive?" American Economic Review 64 (1974), 222-229.

Oates, Wallace E., and Robert M. Schwab, "What Should Local Governments Tax: Income or Property?" (pp. 7-29), in A. Schwartz, ed., City Taxes, City Spending: Essays in Honor of Dick Netzer (Cheltenham, U.K.: Edward Elgar, 2004).

Persson, Torsten, and Guido Tabellini, "Is Inequality Harmful for Growth?" American Economic Review 84 (1994), 600-621.

Phares, Donald, Who Pays State and Local Taxes? (Cambridge, MA: Oelgeschalager, Gunn, and Hain, 1980).

Piketty, Thomas, and Emmanuel Saez, "Income Inequality in the United States, 1913-1998," Quarterly Journal of Economics 118 (2003), $1-39$.

Putnam, Robert D., Bowling Alone: The Collapse and Revival of American Community (New York: Simon \& Schuster, 2000).

Ramcharan, Rodney, "Inequality and Redistribution: Evidence from U.S. Counties and States, 1890-1930," this REVIEW 92 (2010), 561-608. 
Schwabish, Jonathan A., "The Effects of Earnings Inequality on State Social Spending in the United States," Public Finance Review 36 (2008), 588-613.

Schwabish, Jonathan A., Timothy M. Smeeding, and Lars Osberg, "Income Distribution and Social Expenditures: A Cross-National Perspective," (pp. 247-288), in Dmitri B. Papadimitriou, ed., The Distributional Effects of Government Spending and Taxation (Northampton, MA: Edward Elgar Publishing, 2006).

Shelton, Cameron, "The Size and Composition of Government Expenditure," Journal of Public Economics 91 (2007), 2230-2260.

Smeeding, Timothy M., "Twenty Years of Research on Income Inequality, Poverty, and Redistribution in the Developed World: Intro- duction and Overview," Socio-Economic Review 2 (2004) 149163.

Sokoloff, Kenneth L., and Eric M. Zolt, "Inequality and Taxation: Evidence from the Americas on How Inequality May Influence Tax Institutions," Tax Law Review 59 (2005), 167-241.

Suits, Daniel B., "Measurement of Tax Progressivity," American Economic Review 67 (1977), 747-752.

Wilkinson, Richard, and Kate Pickett, The Spirit Level: Why More Equal Societies Almost Always Do Better (New York: Bloomsbury Press, 2009).

Zolt, Eric M., "Inequality, Collective Action, and Taxing and Spending Patterns of State and Local Governments," Tax Law Review 62 (2009), 445-539. 